\title{
Preventive Effects of Flavonoids on Alloxan-Induced Diabetes Mellitus in Rats
}

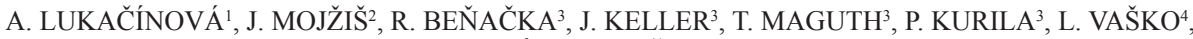 \\ O. RÁCZ $Z^{3}$, F. NIŠTIAR ${ }^{3}$
}
${ }^{1}$ Department of Physiology, ${ }^{2}$ Department of Pharmacology, ${ }^{3}$ Department of Pathological Physiology,
Faculty of Medicine, Šafárik University, Košice, Slovak Republic
${ }^{4}$ Department of Chemistry, Biology and Biochemistry, University of Veterinary Medicine Košice,
Slovak Republic

Received July 4, 2006

Accepted March 13, 2008

\begin{abstract}
Lukačínová A., J. Mojžiš, R. Beňačka, J. Keller, T. Maguth, P. Kurila, L. Vaško, O. Rácz, F. Ništiar: Preventive Effects of Flavonoids on Alloxan-Induced Diabetes Mellitus in Rats. Acta Vet. Brno 2008, 77: 175-182.

The aim of the present study was the evaluation of possible protective effects of quercetin and chrysin in experimental alloxan-induced diabetes in rats. Alloxan was injected at a single dose of $60 \mathrm{mg} / \mathrm{kg}$ (into the tail vein) for diabetes induction.

Quercetin (50 and $100 \mathrm{mg} / \mathrm{kg}$; orally) and chrysin (50 and $100 \mathrm{mg} / \mathrm{kg}$; orally) were administered daily for 3 days prior and 7 days after alloxan injection. Alloxan induced a significant increase of glycaemia $(p<0.001)$ in comparison with control animals.

Quercetin at both doses prevented serum glucose elevation $(p<0.001)$. However, the protective effect of chrysin was weaker and surprisingly, most prominent at the lower dose $(p<0.05$; $p<0.01)$. On the other hand, glycosuria was increased in all groups of animals receiving alloxan. We suggest that the protective effect of the used flavonoids in experimental diabetes mellitus may be related to their antioxidative/chelatory properties. Increased glycosuria indicated that inhibition of renal glucose reabsorption may also play a role in the hypoglycaemic effect of both flavonoids.
\end{abstract}

Flavonoids, quercetin, chrysin, alloxan-induced diabetes, preventive effect, oxidative stress

Increasing evidence from both experimental and clinical studies suggests that oxidative stress plays a major role in the pathogenesis of diabetes mellitus. Free radicals are formed disproportionately in diabetes by glucose oxidation, non-enzymatic glycation of proteins, and the subsequent oxidative degradation of glycated proteins (Maritim et al. 2003; Mehta et al. 2006). Abnormally high levels of free radicals and the simultaneous decline of antioxidant defence mechanisms may lead to the damage of cellular organelles and enzymes (Bartošíková et al. 2003b; El Naggar et al. 2005), increased lipid peroxidation, and development of insulin resistance. These consequences of oxidative stress may promote the development of complications of diabetes mellitus. Recent experimental and clinical studies have uncovered new insights into the role of oxidative stress in diabetic complications, suggesting a different and innovative approach to a possible "causal" antioxidant therapy, e.g. the flavonoids.

Flavonoids (more than 8000) constitute the largest and most important group of polyphenolic compounds in plants. They are widely distributed in many frequently consumed beverages and food products of a plant origin, such as fruit, vegetables, wine, tea, and cocoa (Ross and Kasum 2002). The biological activity of food-borne polyphenolics has attracted interest since the work of Bentsáth et al. (1936) who proposed that the flavonols were an essential dietary factor contributing to the maintenance of capillary permeability. Although this hypothesis was later abandoned, the growing interest in dietary antioxidants

Address for correspondence:

Prof. MVDr. František Ništiar, Csc.

Department of Pathological Physiology

Faculty of Medicine, Safárik University

Trieda SNP 1, 04066 Košice, Slovak republic
Phone: +421556402279
Fax: +42155642 3350
E-mail: nifran@central.medic.upjs.sk
http://www.vfu.cz/acta-vet/actavet.htm 
and metabolically active phytochemicals over the last decade has focused attention on other potentially beneficial effects of flavonoids (Hertog and Hollman 1996; Bartošíková et al. 2003b; Doubek et al. 2005).

It is now widely accepted that dietary polyphenolics may play an important role in protecting the body against chronic diseases, such as cancer, cardiovascular diseases (Mojžišová et al. 1999; Karaca et al. 2006), and diabetes mellitus (Knekt et al. 2002).

The potent antioxidant activity of flavonoids may be their most important function, and underlies many of the above actions in the body. Flavonoids can exert their antioxidant activity by various mechanisms, e.g., by scavenging or quenching free radicals, by chelating metal ions, or by inhibiting enzymatic systems responsible for free radical generation (Bláha et al. 2004; Dias et al. 2005).

As mentioned above, diabetes mellitus is a condition in which free radicals are involved both in human beings and in experimental models. It is well known that alloxan administration causes severe necrosis of pancreatic $\beta$-cells (Dunn and McLetchie 1943; Lankin et al. 2004). It has been suggested that alloxan induces the production of $\mathrm{H}_{2} \mathrm{O}_{2}$ and of some free radicals, such as $\mathrm{O}_{-}^{-}$and $\mathrm{HO}^{-}$that first damage and later bring about the death of the cells (Heikkila et al. 1976; Soto et al. 1994). Therefore, the above model was considered adequate for the study of pathology, such as diabetes mellitus.

The aim of this study was to evaluate the effect of the flavonoids quercetin and chrysin on the alloxan-induced diabetes mellitus.

\section{Materials and Methods}

\section{Chemical agents}

Alloxan $(\mathrm{A})$ as well as quercetin $(\mathrm{Q})$ and chrysin $(\mathrm{Ch})$ were purchased from Sigma Chemical Company (St. Louis, MO).

Animals

The experiments were performed on male Wistar rats (150 - $180 \mathrm{~g})$ obtained from our animal facility. All aspects of animal care complied with the ethical guidelines and technical requirements approved by the Institutional Animal Ethics Committee.

Animals were housed individually in glass-bottomed metabolic cages in an environmentally controlled animal facility $\left(22 \pm 1{ }^{\circ} \mathrm{C}\right.$, humidity $60 \pm 5 \%, 12 \mathrm{~h}$ light : $12 \mathrm{~h}$ dark cycle) with free access to a standard commercial diet and water ad libitum. The weight gain, food and water intake, and urine output were determined daily in the morning.

Induction and treatment of diabetes

Diabetes was induced by a single injection of alloxan $60 \mathrm{mg} / \mathrm{kg}$ b.w. to rats fasting for at least $16 \mathrm{~h}$ through the tail vein in freshly prepared $10 \mathrm{mmol} / 1$ sodium citrate, $\mathrm{pH} 4.5$. Blood glucose levels were measured daily 3 days prior and 7 days after alloxan administration. Development of diabetes mellitus was proven by sustained hyperglycaemia and glycosuria (diabetic rats had glycaemia $>16 \mathrm{mmol} / \mathrm{l}$ ).

The rats were treated with the flavonoids quercetin (Q) and chrysin (Ch) (Fig. 1) for ten consecutive days (3 days before and 7 days after alloxan administration). One dose was given $1 \mathrm{~h}$ immediately before saline/alloxan injection.

\section{Experimental design}

The rats were randomly divided into 10 groups $(n=10)$ as follows:

Group I: control animals I that received vehicles used for flavonoids (carboxymethyl cellulose, 1\%, orally) and for alloxan (saline solution, i.v., in the tail vein).

Groups II and III: animals treated with Q at doses of $50 \mathrm{mg} / \mathrm{kg}$ b.w. (group II) and $100 \mathrm{mg} / \mathrm{kg} \mathrm{b.w.} \mathrm{(group} \mathrm{III),}$ respectively.

Groups IV and V: animals treated with $\mathrm{Ch}$ at doses of $50 \mathrm{mg} / \mathrm{kg}$ b.w. (group IV) and $100 \mathrm{mg} / \mathrm{kg}$ b.w. (group $\mathrm{V})$, respectively.

Group VI: animals treated with alloxan $(60 \mathrm{mg} / \mathrm{kg}$ b.w., i.v.; diabetic control animals - A). The rats developed diabetes within 2 days after alloxan injection as evidenced by sustained hyperglycaemia and glycosuria.

A flavonoids plus alloxan groups (groups VII - X) which received Q or Ch at the same doses and schedule as groups II - V together with alloxan $(60 \mathrm{mg} / \mathrm{kg}$ b.w., i.v. $)$.

The flavonoids were administered orally (by gavage) in carboxymethyl cellulose as a vehicle. Doses of flavonoids were assigned on the basis of experience from literature (Mahesh and Menon 2004; De Boer et al. 2005). 


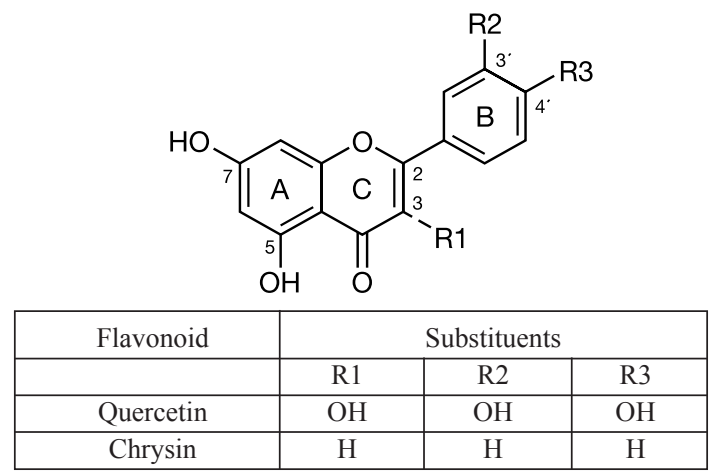

Fig. 1. Structure of quercetin and chrysin

Biochemical evaluation

In order to determine plasma and urine glucose levels, blood and urine samples were collected daily in the morning hours. Blood from the tail vein was collected and centrifuged at $1000 \mathrm{~g}$ for $10 \mathrm{~min}$, and the glucose level was determined by the glucose oxidase-peroxidase enzymatic method (Lab test Set for Glucose, BioLaTest, Lachema, Czech Republic). Twenty-four hour urine samples were collected in metabolic cage urine separator bottles containing $10 \mathrm{ml} 0.33 \mathrm{mmol} / 1$ perchloric acid. One $\mathrm{ml}$ urine was taken for glucose and ketone analyses with the enzymatic (spectrophotometric) method, similarly as in the blood.

Statistical analysis

The data are presented as mean \pm S.E.M. Statistical comparisons were made by one-way analysis of variance (ANOVA) and followed by Student-Neuman-Keuls as the post hoc test. Data were considered significant when $p$ values were lower than 0.05 .

\section{Results}

The effects of quercetin and chrysin on blood glucose levels of control and alloxantreated animals are summarized in Figs. 2 and 3. Additional data as the weight gain, food and water intake, urine volume, glucose index, assimilating coefficient, and mortality are presented in Table 1.

On their own, both quercetin and chrysin had no effect on plasma glucose concentrations of normoglycaemic animals. On the other hand, the alloxan-treated animals consistently exhibited hyperglycaemia. The simultaneous treatment with quercetin (at both doses used) and alloxan significantly reduced the increase in the plasmatic glucose concentration induced by alloxan at any time in the experiment $(p$ $<0.001)$. A slow increase in plasma glucose was observed in animals treated with A + Q50 but it was not significant when compared with control animals. Quercetin at a higher dose completely prevented elevation of plasmatic glucose values. Chrysin at a dose of $50 \mathrm{mg} / \mathrm{kg}$ b.w. also significantly prevented alloxan-induced plasmatic glucose increase $(p<0.05, p<0.01)$. However, the antihyperglycaemic effect of chrysin at a dose of $100 \mathrm{mg} / \mathrm{kg}$ b.w. was surprisingly less significant compared to the lower dose ( $p$ $<0.05)$ on the seventh day after alloxan administration.

Glycosuria was increased significantly and regularly in all diabetic rats compared to non-diabetic animals. Interestingly, in spite of normalized blood glucose levels, significantly high glycosuria was also observed in animals treated with quercetin, particularly at a dose of $100 \mathrm{mg} / \mathrm{kg} \mathrm{b}$.w. Higher levels of glucose in urine were regularly observed in diabetic rats treated with chrysin. Similar to blood glucose data, the higher dose of chrysin showed much lesser effect on glycosuria than the lower one and practically did not differ from the untreated diabetic control. However, glycosuria was also increased in non-diabetic animals receiving chrysin at both doses and quercetin at the dose of $100 \mathrm{mg} / \mathrm{kg} \mathrm{b.w.} \mathrm{(Fig.} \mathrm{4).}$ 


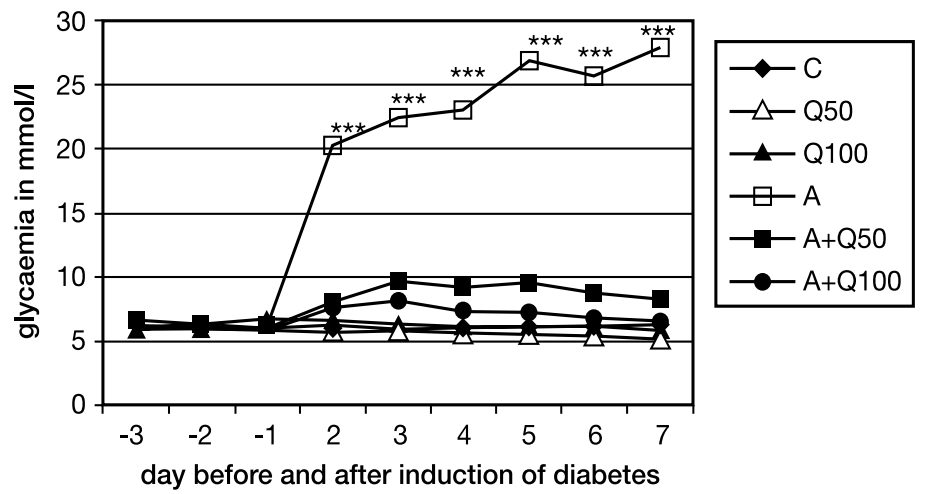

Fig. 2. Effect of quercetin on the concentration of plasma glucose during the development of alloxan-induced diabetes mellitus. Each point represents the mean value; $\mathrm{n}=10$ for each point. $\mathrm{C}$ - control animals, Q50 - animals receiving quercetin at the dose of $50 \mathrm{mg} / \mathrm{kg}$ b.w.; Q100 - animals receiving quercetin at the dose of $100 \mathrm{mg} / \mathrm{kg}$ b.w.; A - alloxan-treated animals; A+Q50 - animals treated with alloxan and quercetin at the dose of $50 \mathrm{mg} / \mathrm{kg}$ b.w.; A+Q100 - animals treated with alloxan and quercetin at the dose of $100 \mathrm{mg} / \mathrm{kg} \mathrm{b.w.;}$

$* * * p<0.001$ alloxan-treated animals vs. all groups

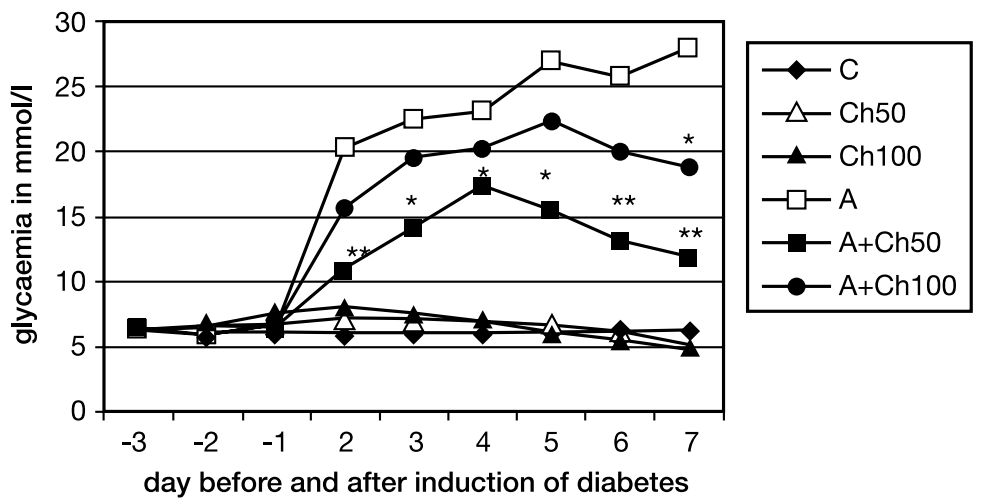

Fig. 3. Effect of chrysin on the concentration of plasma glucose during the development of alloxan-induced diabetes mellitus. Each point represents the mean value; $\mathrm{n}=10$ for each point. $\mathrm{C}-$ control animals, Ch50 animals receiving chrysin at the dose of $50 \mathrm{mg} / \mathrm{kg}$; Ch100 - animals receiving chrysin at the dose of $100 \mathrm{mg} / \mathrm{kg}$ b.w.; A - alloxan-treated animals; A+Ch50 - animals treated with alloxan and chrysin at the dose of $50 \mathrm{mg} / \mathrm{kg}$ b.w.; A+Ch100 - animals treated with alloxan and chrysin at the dose of $100 \mathrm{mg} / \mathrm{kg}$ b.w.; $* p<0.5 ; * * p<0.01$ vs. alloxan-treated animals

\section{Discussion}

The possible sources of oxidative stress in the pathogenesis of diabetes and diabetic complications have been extensively studied for years both in animal models and in clinical setting. Certain studies have found increased lipid peroxides or ROS and oxidative stress (or both) in different animal models of diabetes (Anjaneyulu and Chopra 2004; Mehta et al. 2006). However, the results in clinical practice are not unequivocal and the usefulness of antioxidant therapy in diabetic patients is not convincing (Newsholme et al. 2007).

The unique capacity of alloxan to selectively destroy the pancreatic beta cells was first described by Dunn and McLetchie (1943). Several researchers have proposed that free 
Table 1. Body weight gain, food and water intake, output of urine, glucose index (GI; glucose in food/glycaemia), assimilating coefficient (AQ; glucose in food/glucose output in urine) of rats treated with quercetin and chrysin

\begin{tabular}{|l|c|c|c|c|c|c|c|}
\hline $\begin{array}{l}\text { Treatment } \\
\text { group }\end{array}$ & $\begin{array}{l}\text { Body wt } \\
\text { gain }(\mathrm{g})\end{array}$ & $\begin{array}{l}\text { Food } \\
\text { intake (g) }\end{array}$ & $\begin{array}{l}\text { Water } \\
\text { intake }(\mathrm{ml})\end{array}$ & $\begin{array}{l}\text { Volume of } \\
\text { urine }(\mathrm{ml})\end{array}$ & GI & AQ & Mortality \% \\
\hline C & $32 \pm 3$ & $19.6 \pm 4$ & $26.8 \pm 6$ & $14.8 \pm 2$ & 1.61 & 0.99 & 0 \\
\hline Q50 & $29 \pm 4$ & $21.3 \pm 4$ & $27.7 \pm 5$ & $16.1 \pm 2$ & 1.69 & 0.99 & 0 \\
\hline Q100 & $34 \pm 4$ & $20.6 \pm 5$ & $25.9 \pm 6$ & $17.0 \pm 3$ & 1.66 & 0.98 & 0 \\
\hline Ch50 & $31 \pm 5$ & $22.3 \pm 6$ & $28.6 \pm 8$ & $18.4 \pm 3$ & 1.69 & 0.97 & 0 \\
\hline Ch100 & $29 \pm 6$ & $21.9 \pm 5$ & $33.2 \pm 8$ & $20.3 \pm 5$ & 1.61 & 0.94 & 0 \\
\hline A & $-2 \pm 5$ & $32.6 \pm 7$ & $96.0 \pm 16$ & $92.9 \pm 9$ & 0.58 & 0.46 & 40 \\
\hline A+Q50 & $27 \pm 6$ & $22.2 \pm 4$ & $28.1 \pm 4$ & $19.3 \pm 4$ & 1.35 & 0.95 & 0 \\
\hline A+Q100 & $21 \pm 5$ & $24.6 \pm 3$ & $33.7 \pm 5$ & $24.6 \pm 4$ & 1.92 & 0.86 & 0 \\
\hline A+Ch50 & $18 \pm 7$ & $26.8 \pm 6$ & $52.2 \pm 7$ & $38.1 \pm 5$ & 1.15 & 0.78 & 20 \\
\hline A+Ch100 & $12 \pm 8$ & $31.7 \pm 5$ & $68.1 \pm 9$ & $61.4 \pm 6$ & 0.84 & 0.62 & 20 \\
\hline
\end{tabular}

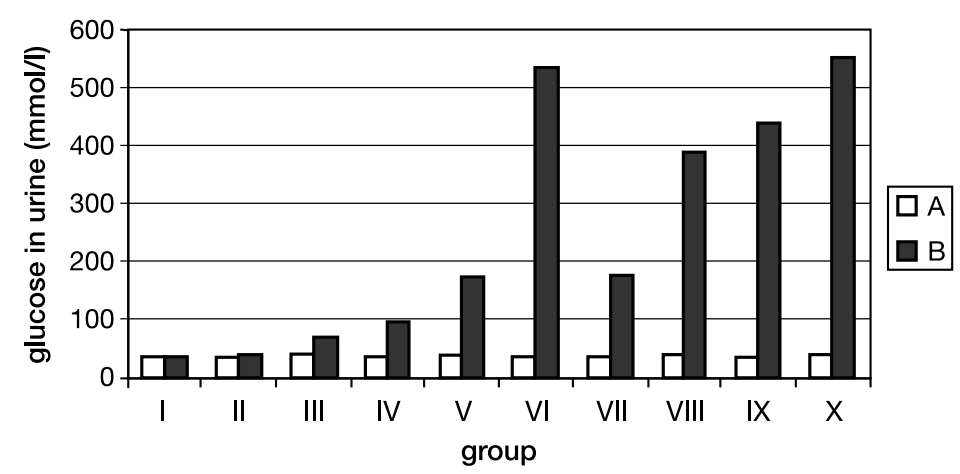

Fig. 4. Effect of quercetin and chrysin on glucosuria in rats. A - three days before and B - seven days after alloxan administration. Goups: I - C; II - Q50; III - Q100; IV - Ch50; V - Ch100; VI - A; VII - A+Q50; VIII - A+Q100; IX - A+Ch50; X - A+Ch100

radicals take part in the cell damage produced by alloxan. Alloxan, a chemical diabetogen, is reduced in the presence of glutathione via the alloxan radical into dialuric acid. During this redox cycling process, reactive oxygen species are formed that destroy beta-cells in islets of Langerhans (Winterbourn and Munday 1989). Moreover, it is suggested that transitional metals such as iron, zinc and copper may be involved in alloxan toxicity (Szkudelski 2001). The role of transitional metals in alloxan-induced diabetes was also documented in the study of El-Hage et al. (1986) who found that ICRF-187 (dexrazoxane, Cardioxan), a metal chelator with no free radical scavenging activity prevented alloxan-induced hyperglycaemia in mice.

The present study demonstrates that quercetin, and partially also chrysin, prevented the rise in plasma glucose induced by alloxan in rats. This is consistent with the previous report on the effect of quercetin on alloxan-induced diabetes mellitus by Nuraliev and Avezov (1992), and streptozotocin-induced diabetes mellitus in rats (Mahesh and Menon 2004; Coskun et al. 2005). They found that quercetin normalizes glycaemia in alloxan-treated animals, too. On the other hand, there is no mention in literature of the effect of chrysin on this type of experimental diabetes mellitus.

Our results showed that the protective effect of quercetin was significantly stronger than the effect of chrysin. This difference in the protective effects may be explained by structural differences between them. A close structure-activity relationship of flavonoids in antioxidant effects has been clearly demonstrated (Chen et al. 2002). The structural requirement considered to be essential for effective radical scavenging by flavonoids is 
the presence of a 3',4'-dihydroxy, i.e., a o-dihydroxy group (catechol structure) in the B ring, possessing electron donating properties and being a radical target. Furthermore, the 3-OH moiety of the $\mathrm{C}$ ring is also beneficial for the antioxidant activity of flavonoids. The C2 - C3 double bond enhances further the radical-scavenging capacity (Firuzi et al. 2005). Moreover, the presence of the catechol group in the B-ring, the 3-hydroxyl group in the $\mathrm{C}$-ring as well as the presence of the 2,3-double bond in the $\mathrm{C}$ ring are also important for the $\mathrm{Fe}^{3+}$ reducing activity. On the other hand, the copper reducing activity seems to depend largely on the number of hydroxyl groups present in the flavonoid molecules (Mira et al. 2002).

The pharmacodynamic profile of quercetin has been well studied (Okamoto 2005). Indeed, the ability of quercetin to protect against oxidative stress-induced cellular damage (such as lipid peroxidation of membranes and subsequent membrane degradation) is associated with free radical scavenging as well as chelatory properties.

(Mira et al. 2002; Anjaneyulu and Chopra 2004). On the other hand, it was found that chrysin had only a moderate antioxidant effect and almost no metal chelatory properties (Kubo et al. 2000; Furusawa et al. 2005).

Our results showed that a daily treatment with quercetin at doses of $50 \mathrm{mg} / \mathrm{kg}$ b.w. and/or $100 \mathrm{mg} / \mathrm{kg} \mathrm{b.w.} \mathrm{prevented} \mathrm{a} \mathrm{steep} \mathrm{onset} \mathrm{of} \mathrm{hyperglycaemia} \mathrm{after} \mathrm{alloxan} \mathrm{administration}$ and maintained blood glucose values closely above healthy controls for the whole period of observation. Effects of chrysin were less prominent and apparently better at the lower than the higher dose. We suggest that it may be the result of a different chemical structure of both flavonoids. Our results support the opinion that the most important criterion in protecting live cells from the oxidative stress is the ortho arrangement of the two hydroxyl groups (free catechol grouping) in the B-ring and the 3-hydroxyl group in C-ring. Quercetin meets this criterion, whereas this feature is absent in chrysin.

On the other hand, both flavonoids showed an unexpected effect on glycosuria. High glycosuria persisted in chrysin-treated diabetic rats. Moreover, in rats not treated by alloxan and receiving only quercetin, the glucose content in urine was also higher than in control animals. There is no report on the glycosuric effect of both flavonoids in the literature and we can currently only speculate about it. It is concluded that some flavonoids or plant extracts with a high content of flavonoids may cause potent inhibition of renal glucose reabsorption through inhibition of the sodium-glucose symporters located in the proximal renal tubule (Hongu et al. 1998; Maghrani et al. 2005).

In spite of this, our results show that oral administration of quercetin and chrysin had a beneficial effect on the diabetic state reducing hyperglycaemia. From the results of clinical studies (Knekt et al. 2002) it is evident without any doubt that the reduction of hyperglycaemia is the most important factor in the prevention of chronic microvascular complications of diabetes mellitus (retinopathy, nepropathy, neuropathy and diabetic foot) as well as in the prevention of the accelerated atherosclerosis-related conditions (myocardial infarction, stroke). Several researchers have demonstrated that flavonoids act as reducers of hyperglycaemia (Anjaneyulu and Chopra 2004; Dene et al. 2005) and there is reduced non-enzymatic glycation of proteins in animals. Studies with flavonoids are underway to further elucidate their mechanism of action. Further research must also determine what combinations might prove efficacious given the large number of persons taking nutriceuticals.

In summary, this study suggests that the induction of diabetes mellitus by alloxan in rats may be prevented by quercetin and partially by chrysin administration. We hypothesized that this effect may be the result of antiradical/chelatory properties of the flavonoids used. However, inhibition of renal glucose reabsorption may be also involved in the hypoglycaemic effect of these flavonoids. 


\section{Preventívny účinok flavonoidov na aloxánový diabetes mellitus u potkanov}

Ciel'om predloženej štúdie bolo sledovanie protektívneho účinku kvercetínu a chryzínu na experimentálny aloxánom vyvolaný diabetes mellitus u potkanov. Diabetes bol vyvolaný jednou dávkou aloxánu $60 \mathrm{mg} / \mathrm{kg}$ (do chvostovej žily).

Kvercetín a chryzín boli podávané (perorálne v dávke 50 a $100 \mathrm{mg} / \mathrm{kg}$ živej hmotnosti) 3 dní pred a 7 dní po aplikácii aloxánu. Aloxán vyvolal významný vzostup glykémie $(p<0,001)$ v porovnaní s kontrolnými zvieratami.

Aplikácia kvercetínu v oboch dávkach zabránila zvýšeniu glykémie $(p<0,001)$. Aj ked' bol protektívny účinok chryzínu slabší, prekvapujúco bol výraznejší pri nižšej dávke $(p<0,05 ; p<0,01)$. U všetkých zvierat ošetrených aloxánom bola zaznamenaná výrazná glykozúria. Predpokladáme, že protektívny účinok flavonoidov voči experimentálnemu diabetes mellitus spočíva $\mathrm{v}$ ich antioxidačných/chelatačných vlastnostiach. Zvýšená glykozúria naznačuje, že inhibícia reabsorbcie glukózy v obličkách zohráva významnú úlohu v hypoglykemickom účinku oboch flavonoidov.

\section{Acknowledgement}

This research was supported by the Grant Agency of the Ministry of Education, Slovak Republic (VEGA 1/3494/06). The authors express their thanks to MVDr. Agnesa Ništiarová for the animal care and Mr. Martin Kurpas for technical assistance.

\section{References}

ANJANEYULU M, CHOPRA K 2004: Quercetin, an anti-oxidant bioflavonoid, attenuates diabetic nephropathy in rats. Clin Exp Pharmacol Physiol 31: 244-248

BARTOŠ́KOVÁ L, NEČAS J, SUCHÝ V, KUBÍNOVÁ R, VESELÁ D, BENEŠ L, BARTOŠÍK T, ILLEK J, ŠALPLACHTA J, KLUSÁKOVÁ J, BARTOŠOVÁ L, STRNADOVÁ V, FRÁŇA P, FRÁŇOVÁ J 2003a: Monitoring of antioxidative effect of morine in alloxan-induced diabetes mellitus in the laboratory rat. Acta Vet Brno 72: 191-200

BARTOŠÍKOVÁ L, NEČAS J, SUCHÝ V, KUBÍNOVÁ R, VESELÁ D, BENEŠ L, ILLEK J, ŠALPLACHTA J, FLORIAN T, FRYDRYCH M, KLUSÁKOVÁ J, BARTOŠÍK T, FRÁŇA L, FRÁŇA P, DZÚROVÁ J 2003 b: Antioxidative effect of morine in ischemia-reperfusion of kidneys in the laboratory rat. Acta Vet Brno 72: $87-94$

BENTSÁTH A, RUSZNYÁK S, SZENT-GYÖRGYI A 1936: Vitamin nature of flavones. Nature 138: 798

BLÁHA L, KOPP R, ŠIMKOVÁ K, MAREŠ J 2004: Oxidative stress biomarkers are modulated in silver carp (Hypophthalmichthys molitrix Val.) exposed to microcystin-producing cyanobacterial water bloom. Acta Vet Brno 73: 477-482

CHEN JW, ZHU ZQ, HU TX, ZHU DY 2002: Structure-activity relationship of natural flavonoids in hydroxyl radical-scavenging effects. Acta Pharmacol Sin 23: 667-672

COSKUN O, KANTER M, KORKMAZ A, OTER S 2005: Quercetin, a flavonoid antioxidant, prevents and protects streptozotocin-induced oxidative stress and $\beta$-cell damage in rat pancreas. Pharmacol Res 51: $117-123$

DE BOER VCJ, DIHAL AA, VAN DER WOUDE H, ARTS ICW, WOLFFRAM S, ALINK GM, RIETJENS IMCM, KEIJER J, HOLLMAN PCH 2005: Tissue distribution of quercetin in rats and pigs. J Nutr 135: 17181725

DENE BA, MARITIM AC, SANDERS RA, WATKINS JB 2005: Effects of antioxidant treatment on normal and diabetic rat retinal enzyme activities. J Ocular Pharmacol Ther 21: 28-35

DIAS AS, PORAWSKI M, ALONSO M, MARRONI N, COLLADO PS, GONZÁLEZ-GALLEGO J 2005 : Quercetin decreases oxidative stress, NF- $\mathrm{KB}$ activation, and iNOS overexpression in liver of streptozotocininduced diabetic rats. J Nutr 135: 2299-2304

DOUBEK J, VOLNÝ T, LOJEK A, KNOTKOVÁ Z, KOTRBÁČEK V, SCHEER P, HOLEŠOVSKÁ Z 2005: Effect of stilbene resveratrol on haematological indices of rats. Acta Vet Brno 74: 205-208

DUNN JS, MCLETCHIE NGB 1943: Experimental alloxan diabetes in the rat. Lancet 1943: 484-487

EL-HAGE A, HERMAN EH, YANG GC, CROUCH RK, FERRANS VJ 1986: Mechanism of the protective activity of ICRF-187 against alloxan-induced diabetes in mice. Res Commun Chem Pathol Pharmacol 52: 341-360

EL NAGGAR EMB, BARTOŠÍKOVÁ L, ŽEMLIČKA M, ŠVAJDLENKA E, RABIŠKOVÁ M, STRNADOVÁ V, NEČAS J 2005: Antidiabetic effect of Cleome droserifolia aerial parts: Lipid peroxidation-induced oxidative stress in diabetic rats. Acta Vet Brno 74: 347-352

FIRUZI O, LACANNA A, PETRUCCI R, MARROSU G, SASO L 2005: Evaluation of the antioxidant activity 
of flavonoids by "ferric reducing antioxidant power" assay and cyclic voltammetry. Biochim Biophys Acta 1721: $174-184$

FURUSAWA M, TANAKA T, ITO T, NISHIKAWA A, YAMAZAKI N, NAKAYA K, MATSUURA N, TSUCHYIA H, NAGAYAMA M, IINUMA M 2005: Antioxidant anctivity of hydroxyflavonoids. J Health Sci 51: $376-378$

HEIKKILA R, WINSTON B, COHEN G 1976: Alloxan induced-diabetes evidence for hydroxyl radical as a cytotoxic intermediate. Biochem Pharmacol 25: 1085-1092

HERTOG MG, HOLLMAN PC 1996: Potential health effects of the dietary flavonol quercetin. Eur J Clin Nutr 50: $63-71$

HONGU M, TANAKA T, FUNAMI N, SAITO K, ARAKAWA K, MATSUMOTO M, TSUJIHARA K. 1998: $\mathrm{Na}(+)$-glucose cotransporter inhibitors as antidiabetic agents. II. Synthesis and structure-activity relationships of 4'-dehydroxyphlorizin derivatives. Chem Pharm Bull (Tokyo) 46: 22-33

KARACA T, CEMEK M, KANTER M 2006: Lipid peroxidation and antioxidant levels, and alpha naphthyl acetate esterase activity of peripheral blood lymphocytes in Mallard, Muscovy and Pekin ducks. Acta Vet Brno 75: $33-38$

KNEKT P, KUMPULAINEN J, JÄRVINEN R, RISSANEN H, HELIÖVAARAM, REUNANENA, HAKULINEN T, AROMAA A 2002: Flavonoid intake and risk of chronic diseases. Am J Clin Nutr 76: 560-568

KUBO I, KINST-HORI I, CHAUDHURI SK, KUBO Y, SANCHEZ Y, OGURA T 2000: Flavonols from Heterotheca inuloides: tyrosinase inhibitory activity and structural criteria. Bioorg Med Chem 8: 1749-1755

LANKIN VZ, KORCHIN VI, KONOVALOVA GG, LISINA MO, TIKHAZE AK, AKMAEV IG, 2004: Role of antioxidant enzymes and antioxidant compound probucol in antiradical protection of pancreatic beta-cells during alloxan-induced diabetes. Bull Exp Biol Med 137: 20-23

MAGHRANI M, MICHEL JB, EDDOUKS M 2005: Hypoglycaemic activity of Retama raetam in rats. Phytother Res 19: $125-128$

MAHESH T, MENON VP 2004: Quercetin alleviates oxidative stress in streptozotocin-induced diabetic rats. Phytother Res 18: 123-127

MARITIM AC, SANDERS RA, WATKINS JBIII 2003: Diabetes, oxidative stress, and antioxidants: a review. J Biochem Mol Toxicol 17: 24-38

MEHTA JL, RASOULI N, SINHA AK, MOLAVI B 2006: Oxidative stress in diabetes: A mechanistic overview of its effects on atherogenesis and myocardial dysfunction. Int J Biochem Cell Biol 38: 794-803

MIRA L, FERNANDEZ MT, SANTOS M, ROCHA R, FLORENCIO MH, JENNINGS KR 2002: Interactions of flavonoids with iron and copper ions: a mechanism for their antioxidant activity. Free Radic Res 36: 1199-1208

MOJŽIŠOVÁ G, PETRÁŠOVÁ D, KOPROVIČOVÁ J 1999: Flavonoids with antioxidant action and their effect on human health. Slovakofarma Rev 9: 35-37

NEWSHOLME P, HABER EP, HIRABARA SM, REBELATO ELO, PROCOPIO J, MORGAN D, OLIVEIRAEMILIO HC, CARPINELLI AR, CURI R 2007: Diabetes associated cell stress and dysfunction: role of mitochondrial and non-mitochondrial ROS production and activity. J Physiol 583: 9-24

NURALIEV I, AVEZOV GA 1992: The efficacy of quercetin in alloxan diabetes. Eksp Klin Farmakol 55: 42-44

OKAMOTO T 2005: Safety of quercetin for clinical application (Review). Int J Mol Med 16: 275-278

ROSS JA, KASUM CM 2002: Dietary flavonoids: bioavailability, metabolic effects, and safety. Annu Rev Nutr 22: $19-34$

SOTO C, MURIEL P, REYES JL 1994: Pancreatic lipid peroxidation in alloxan-induced diabetes mellitus. Arch Med Res 25: 377-380

SZKUDELSKI T 2001: The mechanism of alloxan and streptozotocin action in B cells of the rat pancreas. Physiol Res 50: 536-546

WINTERBOURN CC, MUNDAY R 1989: Glutathione-mediated redox cycling of alloxan. Mechanisms of superoxide dismutase inhibition and of metal-catalyzed $\mathrm{OH}$ formation. Biochem Pharmacol 38: 271-277 